\title{
Kesetaraan Gender dalam Perekrutan Aparatur Sipil Negara Menempati Jabatan Struktural di Pemerintah Daerah Provinsi Nusa Tenggara Timur
}

\section{Gender Equality in Recruitment of State Civil Servants to Occupy Structural Positions in the Regional Government of East Nusa Tenggara Province}

\author{
Eugenia Natalia Meo 1), \& Veronika Ina Assan Boro ${ }^{2)}$ \\ 1) Program Studi Magister Ilmu Politik, Fakultas Ilmu Sosial dan Ilmu Politik, Universitas \\ Diponegoro, Indonesia \\ 2) Program Studi Ilmu Pemerintahan, Universitas Katholik Widya Mandira, Kupang
}

Diterima: 19 September 2020; Disetujui:21 Desember 2020; Dipublish: 31 Januari 2021

\begin{abstract}
Abstrak
Masalah ketidakadilan gender merupakan salah satu bentuk ketidakadilan sosial di Indonesia yang selalu menjadi tema menarik dan tetap akan menjadi tema penting dalam setiap pemikiran dan konsepsi tentang kemasyarakatan di masa mendatang. Penelitian ini bertujuan untuk mendeskripsikan proses rekrutmen ASN dalam menempati jabatan struktural di Pemda Provinsi Nusa Tenggara Timur dan juga faktor-faktor yang mempengaruhi minimnya ASN Perempuan menempati jabatan struktural. Metode penelitian yang digunakan kualitatif dengan pengumpulan data primer melalui teknik wawancara mendalam dan observasi, sedangkan data sekunder dikumpulkan melalui arsip dan dokumentasi. Hasil penelitian menunjukan bahwa proses perekrutan Aparatur Sipil Negara menempati jabatan struktural sudah sesuai dengan aturan dalam Undang-Undang Aparatur Sipil Negara No. 5 Tahun 2014, meskipun belum sepenuhnya diterapkan secara keseluruhan. Selain karena regulasi yang belum dijalankan dengan maksimal teridentifikasi juga faktor lain yang mempengaruhi juga karena kurangnya minat atau kemauan dari perempuan sendiri, ruang dan peluang diberikan tetapi kesadaran dari perempuan untuk ambil bagian masih sangat minim.
\end{abstract}

Kata Kunci : Kesetaraan Gender, Rekrutmen, Aparatus Sipil Negara, Jabatan Struktural

\begin{abstract}
The issue of gender injustice is a form of social injustice in Indonesia which has always been an interesting theme and will remain an important theme in every thought and conception of society in the future. This study aims to describe the recruitment process for ASNs in structural positions in the Provincial Government of East Nusa Tenggara and also the factors that influence the lack of female ASN occupying structural positions. The research method used is qualitative by collecting primary data through in-depth interviews and observation techniques, while secondary data is collected through archives and documentation. The results showed that the recruitment process for State Civil Servants to occupy structural positions was in accordance with the rules in the State Civil Apparatus Law No. 5 of 2014, although not fully implemented as a whole. Apart from the fact that regulations that have not been fully implemented have been identified as well as other factors that influence as well as a lack of interest or willingness from women themselves, space and opportunities are provided but awareness of women to take part is still very minimal.
\end{abstract}

Keywords: Gender Equality, Recruitment, Civil State Apparatus, Structural Position

How to Cite: Meo, E.N. \& Boro, V.I.A. (2021). Kesetaraan Gender dalam Perekrutan Aparatur Sipil Negara Menempati Jabatan Struktural di Pemda Provinsi Nusa Tenggara Timur. PERSPEKTIF, 10(1): 204-210 


\section{PENDAHULUAN}

Salah satu sendi utama dalam demokrasi yaitu Kesetaraan Gender karena menjamin bebasnya untuk berpeluang dan mengakses bagi seluruh elemen masyarakat. Gagalnya dalam mencapai cita - cita demokrasi, seringkali dipicu oleh ketidaksetaraan dan ketidakadilan gender. Sampai saat ini diskriminasi berbasis pada gender masih terasakan hampir di seluruh dunia. Dalam konteks ini, kaum perempuan yang paling berpotensi mendapatkan perlakuan diskriminatif, meski tidak menutup kemungkinan laki-laki juga dapat mengalaminya. Gender dipersoalkan karena secara sosial telah melahirkan perbedaan peran, tanggung jawab, hak dan fungsi serta ruang aktivitas laki-laki dan perempuan dalam masyarakat. Perbedaan jenis kelamin sering dipergunakan masyarakat untuk membedakan dan membentuk pembagian peran (kerja) laki laki yang mempunyai peran sebagai pencari nafkah (luar rumah) dan peran perempuan sebagai pengurus rumah tangga (dalam rumah), atas dasar perbedaan tersebut mengakibatkan terjadilah pembagian peran gender yaitu peran domestik dan peran publik. Peran domestik cenderung tidak menghasilkan uang, kekuasaan dan pengaruh. Peran ini lebih banyak diserahkan kepada kaum perempuan, sedangkan peran publik yang menghasilkan uang, kekuasaan dan pengaruh diserahkan kepada kaum laki-laki.Akibat pembagian kerja yang tidak seimbang melahirkan ketimpangan peran laki-laki dan perempuan.

Konsep gender juga termasuk karakteristik atau ciri-ciri laki-laki dan perempuan yang merupakan bentukan sosial dan budaya oleh keluarga atau masyarakat. Misalnya, secara umum, pekerjaan memasak, mengurus anak, mencuci selalu disebutkan hanya sebagai pekerjaan perempuan. Pandangan seperti ini merupakan ciptaan masyarakat dari budaya tertentu, padahal pekerjaan tersebut dapat juga dipertukarkan dengan laki-laki atau dapat dikerjakan oleh laki-laki. Karakteristik atau ciri-ciri ini menciptakan pembedaan antara laki-laki dan perempuan yang disebut pembedaan gender. Ini sering mengakibatkan peran sosial yang berbeda antara laki-laki dan perempuan. Hal inilah yang berdampak pada pembagian peran antara laki-laki dan perempuan dalam kehidupan sosial budaya yang berdampak pada ketidakadilan gender. Masalah ketidakadilan gender merupakan salah satu bentuk ketidakadilan sosial di Indonesia yang selalu menjadi tema menarik dan tetap akan menjadi tema penting dalam setiap pemikiran dan konsepsi tentang kemasyarakatan di masa mendatang. Hal ini dikarenakan ketidakadilan gender merupakan kondisi kesenjangan dan ketimpangan dari sistem struktur sosial budaya dimana baik perempuan dan laki-laki menjadi korban dari sistem tersebut. Ketidakadilan gender terjadi karena adanya keyakinan dan pembenaran yang ditanamkan sepanjang peradapan manusia dalam berbagai bentuk ketidakadilan gender seperti marginalisasi, subordinasi, pandangan stereotype, kekerasan, dan beban ganda. Bentuk-bentuk ketidakadilan gender harus dihapuskan karena merugikan perempuan dan laki-laki, oleh karena itu kesetaraan gender menjadi sangat penting untuk diperjuangkan.

Perjuangan untuk mewujudkan kesetaraan gender bukanlah persoalan mudah sebagaimana membalikan telapak tangan, masih butuh waktu yang panjang untuk benarbenar menghapuskan diskriminasi/ketidakdilan terhadap perempuan terutama di ranah publik seperti di bidang politik dan pemerintahan.

Di Nusa Tenggara Timur ada berbagai kasus bias gender yang terjadi, seperti dalam penelitian ini peneliti ingin membahas tentang adanya bias gender yang terjadi dalam birokrasi dalam hal ini di Pemda Provinsi Nusa Tenggara Timur. Maka dalam penelitian kali ini penulis akan menguraikan dan menjelaskan secara detail fenomena empirik yang terjadi terkait dengan faktor penghambat apa yang menyebabkan minimnya perempuan yang menempati jabatan struktural di Pemda Provinsi NTT. Beberapa studi mengkonfirmasi hal tersebut. Penelitian yang dilakukan oleh (Naimena, 2015) dengan judul penelitian "Rekrutmen Politik ( Kajian Pola Rekrutmen Perempuan Menjadi Kader Partai dan Menempati Jabatan Struktural di Partai PolitikStudi Kasus di PDIP dan GOLKAR Kota Kupang Tahun 2014). Penelitian sejenis yang lain dilakukan oleh (Astuti, 2013) yang meneliti Peluang PNS Perempuan Dalam Memperoleh Jabatan Struktural : Studi Kualitas Kesetaraan Gender Di Pemerintah Kota Semarang. Sementara itu, penelitian yang dilakukan oleh (Sahirah, Setiawati, \& Burhanuddin, 2015) 
fokus pada pengarusutamaan gender dalam promosi jabatan di BKD pemerintah kota Makassar. Seperti yang diuraikan sebelumnya, para peneliti ini memiliki kesamaan pandangan bahwa bias gender masih terjadi dalam berbagai sektor baik birokrasi maupun politk. Beberapa penelitian yang diulas di atas belum ada satupun yang membahas tentang kesetaraan gender di pemprov NTT. Sangat penting adanya perwakilan perempuan dalam sebuah jabatan struktural pemerintahan, sehingga hal-hal yang menyangkut dengan masalah perempuan bisa disuarakan dan di bahas dengan baik demi kesejahteraan bersama.

\section{METODE PENELITIAN}

Penelitian ini digunakan dengan metode kualitatif. Menurut (Creswell, 2016) penelitian kualitatif merupakan metode yang digunakan untuk mengeksplorasi dan paham makna yang oleh beberapa individu atau sekelompok orang dianggap berasal dari masalah sosial dan kemanusiaan. Creswell mengemukakan proses penelitian kualitatif melibatkan beberapa upaya penting, misalnya mengajukan pertanyaan-pertanyaan dan prosedurprosedur, mengumpulkan data, yang spesifik dari para partisipan, menganalisis data secara induktif mulai dari tema-tema yang khusus ke tema-tema yang umum, serta menafsirkan makna data. Metode penelitian yang digunakan dengan tipe penelitian deskriptif kualitatif dan lokus penelitian di BKD Provinsi Nusa Tenggara Timur. Data yang dipakai dalam penelitian ini adalah data primer dan data sekunder. Sumber data yang digunakan dalam bentuk primer data yang diperoleh dari wawancara mendalam dan observasi, sedangklan data sekunder dalam bentuk dokumentasi dan arsip. Penelitian dalam melakukan pengumpulan data menggunakan teknik triangulasi data dengan menggabungkan beberapa teknik, yakni wawancara mendalam, observasi dan dokumentasi. Wawancara merupakan metode pengumpulan data dengan cara mengunjungi langsung seseorang yang memiliki kapasitas dalam menjawab pertanyaan. Wawancara dilakukan dengan menemui langsung informan terkait. Teknik dokumentasi adalah proses pengumpulan kebutuhan data dengan cara meneliti dokumen yang berkaitan dengan fenomena yang diteliti di lapangan. Peneliti mengumpulkan data dengan cara meneliti arsip dan dokumen-dokumen yang berkaitan dengan obyek yang diteliti.

Alasan penulis menggunakan metode ini karena dapat menggambarkan permasalahan dengan jelas dan terperinci mengenai faktor yang menyebabkan minimnya keterwakilan perempuan dalam menempati jabatan struktural di Pemda Provinsi Nusa Tenggara Timur.

\section{HASIL DAN PEMBAHASAN}

Kesetaraan berasal dari kata setara atau sederajat. Jadi, kesetaraan juga dapat disebut kesederajatan. Menurut Kamus Besar Bahasa Indonesia (KBBI), sederajat artinya sama tingkatan (kedudukan/pangkat). Dengan demikian, kesetaraan menunjukkan adanya tingkatan yang sama, kedudukan yang sama, tidak lebih tinggi atau tidak lebih rendah antara satu sama lain. Kesetaraan manusia bermakna bahwa manusia sebagai makhluk Tuhan mempunyai tingkat atau kedudukan yang sama. Yang membedakan nantinya adalah tingkat ketakwaan manusia terhadap Tuhannya (Nassarudin, 2012). Persamaan kedudukan atau tingkatan manusia ini berimplikasi pada adanya pengakuan akan kesetaraan atau kesederajatan manusia. Jadi, kesetaraan dan kesederajatan tidak sekedar bermakna adanya persamaan kedudukan manusia. Kesederajatan adalah suatu sikap mengakui adanya persamaan derajat, persamaan hak, dan persamaan kewajiban sebagai sesama manusia. Berkaitan dengan dua konsep diatas, maka dalam keragaman diperlukan adanya kesetaraan atau kesederajatan. Artinya, meskipun individu maupun masyarakat adalah beragam dan berbeda-beda, tetapi memiliki dan diakui kedudukan, hak-hak dan kewajiban yang sama baik dalam kehidupan pribadi maupun bermasyarakat. Terlebih dalam kehidupan berbangsa dan bernegara. Kesetaraan merupakan prinsip keadilan pertama (first principle of justice) yang berarti setiap orang memiliki hak yang sama untuk kebebasan dasar yang kompatibel sesuai dengan kebebasan yang diterima orang lain.

Mansour Fakih mengemukakan bahwa analisis gender dalam sejarah pemikiran manusia tentang ketidakadilan sosial dianggap suatu analisis baru yang tidak kalah mendasar dibanding analisis ilmu sosial lainnya, bahkan analisis gender justru ikut mempertajam analisis kritis yang sudah ada, misalnya analisis 
kelas yang dikembangkan oleh Karl Marx ketika melakukan kritik terhadap kapitalisme akan lebih tajam jika pertanyaan tentang gender dikemukakan (Fakih, 1999, hal. 4). Pernyataan Fakih amatlah benar dan sekaligus memperkuat asumsi bahwa gender sebagai sebuah sudut pandang diwarnai oleh ilmu-ilmu sosial yang secara pop disebut "kiri". Sebuah pemikiran ilmu sosial yang dimulai oleh salah satu pemikir terbesar disepanjang zaman, Karl Marx (Nugroho, 2008, hal. 18). Di dalam kasanah keilmuan ini muncul berbagai turunan atau derivate, mulai marxisme, komunisme, sosialisme dan neo-marxsisme atau juga sering disebut "Kiri-Baru". Gender merupakan perbedaan antara laki-laki dan perempuan yang dikonstruksi secara sosial dan kultural yang berkaitan dengan peran, perilaku, dan sifat yang dianggap layak untuk dipertukarkan baik bagi laki-laki maupun perempuan (Azisah, Mustari, Himayah, \& Masse, 2016)

Dari berbagai definisi tersebut, dapat disimpulkan bahwa gender adalah suatu konstruksi atau bentuk social yang sebenarnya bukan bawaan lahir sehingga dapat dibentuk atau diubah tergantung dari tempat, waktu/zaman, suku/ras/bangsa, budaya, status sosial, pemahaman agama, negara ideology, politik, hukum, dan ekonomi. Oleh karenanya gender bukanlah kodrat Tuhan melainkan buatan manusia yang dapat dipertukarkan. Sedangkan jenis kelamin (seks) merupakan kodrat Tuhan (ciptaan Tuhan) yang berlaku di mana saja dan sepanjang masa yang tidak dapat berubah dan dipertukarkan antara jenis kelamin laki-laki dan perempuan. Gender dalam kehidupan sehari-hari sering dipersoalkan karena adanya bias gender. Mulai dari urusan rumah tangga hingga pada rana publik termasuk pada sektor birokrasi maupun politik.

Proses perekrutmen yaitu, proses ataupun kegiatan seleksi pegawai baru maupun lama untuk menempati posisi atau jabatan yang lowong melalui promosi dan mutasi jabatan. Berdasarkan hasil penelitian aspek proses perekrutan ASN untuk menempati jabatan struktural yang lowong pada Pemda Provinsi NTT dilakukan berdasarkan Undang-Undang ASN No 5 Tahun 2014 Tentang Aparatur Sipil Negara dan juga berdasarkan Peraturan Mentri Pendayagunaan Aparatur Negara Dan Reformasi Birokrasi Republik Indonesia Nomor 13 Tahun 2014 Tentang Tata Cara Pengisian
Jabatan Pimpinan Tinggi Secara Terbuka Di Lingkungan Instansi Pemerintah, yakni menggunakan persyaratan berdasarkan kompetensi jabatan yang diperlukan, prestasi kerja, jenjang pangkat yang ditetapkan untuk jabatan tersebut dan tidak membedakan SARA. ASN yang akan diseleksi oleh panitia seleksi (pansel) harus mengikuti beberapa tahapan seleksi mulai dari seleksi administrasi, psikotes, mempresentasikan rencana kerja mereka di depan pansel hingga pada penetapan akhir nanti. Proses yang dilakukan sangat tertutup dan hanya bisa dihadiri oleh Panitia seleksi, Asesor dan Peserta seleksi.

\section{Kompetensi Jabatan yang diperlukan}

Dalam perekrutan ASN untuk menempati jabatan struktural suatu kompetensi sangat diperlukan. Berdasarkan hasil penelitian diketahui bahwa dalam proses perekrutan untuk menempati suatu jabatan struktural seorang ASN harus Kompeten dalam bidangnya. Dengan kata lain, ASN dalam menjalankan tugasnya tentu harus berdasarkan pada profesionalisme dan kompetensi sesuai kualifikasi bidang ilmu yang dimilikinya. Hal ini diungkapkan oleh Bapak Guido El Joacim Laga, S.STP, M.Si ( selaku pejabat fungsional di Bidang Pengembangan Karir Pegawai ( BKD Prov. NTT) yang juga merupakan Accecor untuk Jabatan Pimpinan Tinggi Pratama), "Dalam perekrutan ASN untuk menempati jabatan struktural kompetensi jabatan dari seorang ASN sangat diperlukan, hal ini sangat dibutuhkan karena untuk meningkatkan produktifitas kerja dan menjamin kualitas kerja dari seorang ASN. Kompetensi jabatan sangat diperlukan juga karena berpengaruh terhadap peran, perbuatan, prestasi serta pekerjaan dari seorang ASN itu sendiri".

\section{Prestasi Kerja}

Prestasi kerja sangat penting bagi sebuah organisasi untuk mencapai tujuannya. Dalam konteks pengembangan Sumber Daya Manusia prestasi kerja seorang pegawai dalam sebuah organisasi atau lembaga sangat dibutuhkan untuk mencapai prestasi kerja bagi pegawai itu sendiri dan juga untuk keberhasilan sebuah organisasi. Prestasi kerja merupakan hasil kerja seseorang pegawai selama periode tertentu dibandingkan dengan berbagai kemungkinan misalnya standard, 
target/sasaran atau kriteria yang telah ditentukan terlebih dahulu dan disepakati bersama. Hal ini diungkapkan oleh Ibu Dra. Veneranda Moi (Selaku Kepala Sub Bagian Peningkatan Kapasitas Otda di Setda Provinsi NTT) mengatakan bahwa :

"Kinerja pegawai merupakan suatu hal yang sangat penting dalam usaha organisasi untuk mencapai tujuannya, sehingga berbagai kegiatan harus dilakukan organisasi untuk meningkatkannya. Salah satu diantaranya adalah melalui penilaian prestasi kerja. Penilaian prestasi kerja merupakan proses melalui mana organisasi-organisasi mengevaluasi atau menilai prestasi kerja pegawai. Prestasi kerja yang dicapai pegawai merupakan suatu hal yang sangat penting dalam menjamin kelangsungan hidup organisasi".

Bapak Drs. Mikhael Thomas Susu, M.Si (selaku Panitia Seleksi JPTP Pemprov. NTT) juga memberikan pendapat yang sama bahwa:

"Tujuan dilakukannya penilaian prestasi kerja secara umum adalah untuk memberikan feedback kepada ASN itu sendiri dalam upaya memperbaiki tampilan kerjanya dan upaya meningkatkan produktivitas organisasi. Penilaian prestasi kerja ASN adalah suatu proses kegiatan yang dilakukan untuk mengevaluasi tingkat pelaksanaan pekerjaan dan penilaian terhadap perilaku pegawai. Dan penilaian prestasi kerja ini dituangkan dalam bentuk Sasaran Kerja Pegawai (SKP), yang dulunya dilakukan melalui Daftar Penilaian Pelaksanaan Pekerjaan (DP3). Dengan menerapkan sistem SPK ini, lebih menjamin obyektifitas pembinaan ASN yang dititikberatkan pada sistem prestasi kerja dan juga penilaian akan lebih terukur dan semua unsure penilaian prestasi kerja sekurangkurangnya bernilai baik dalam 2 tahun terakhir sebelum diangkat untuk menduduki jabatan struktural".

Jenjang Pangkat Yang Ditetapkan Untuk Sebuah Jabatan Pangkat merupakan kedudukan yang menunjukan tingkat Jabatan berdasarkan tingkat kesulitan, tanggung jawab, dampak, dan persyaratan kualifikasi pekerjaan yang digunakan sebagai dasar penggajian. Pangkat sebagaimana diatur dalam ayat (1) PP No. 11 Tahun 2017 yang mengatur mengenai gaji, tunjangan, dan fasilitas bagi ASN.

"Jabatan structural hanya bisa diduduki oleh mereka yang berstatus ASN, dan jabatan tersebut diperoleh sesuai dengan kepangkatan. Suatu jabatan itu diperoleh karena orang tersebut dipercayakan untuk mengemban tugas itu sesuai dengan kemampuan, pengalaman dan basic ilmunnya. Dan juga atas dasar pertimbangan sesuai syarat-syarat yang sudah di atur dalam Peraturan Pemerintah Republik Indonesia Nomor 13 Tahun 2002 Tentang Pengangkatan Pegawai Negri Sipil Dalam Jabatan Struktural" (Johanna Lisapaly,S.H,M.Si, selaku Kepala Dinas Pendidikan Provinsi NTT yang juga merupakan salah satu Panitia seleksi JPTP Provinsi NTT) .

\section{Tidak Membedakan Jenis Kelamin, Suku, Agama, Ras, Antar Golongan}

Salah satu factor penting dalam pengelolaan Sumber Daya Manusia Aparatur adalah pelaksanaan dalam pengangkatan dan penempatan dalam jabatan baik structural maupun fungsional. Proses seleksi ASN dalam jabatan struktural yang baik akan menghasilkan penyelenggaraan organisasi yang sehat, namun sebaliknya kesalahan dalam proses pengangkatan dalam jabatan struktural akan memberikan dampak yang tidak sehat antara lain tidak tercapainya tujuan organisasi, hubungan kerja yang tidak harmonis, cara kerja yang tidak efektif dan efisien, serta penyimpangan prosedur kerja. Hal ini didukung dengan hasil wawancara bersama Ibu Dra. Theresia Ratna Dwi Astuti ( selaku Kasubag Tata Usaha Pimpinan Pada Biro Umum Provinsi NTT) mengatakan bahwa: "Menurut saya kita sebagai ASN dalam penempatan sudah jelas diatur melalui Undang-undang ASN tentang manajemen ASN yaitu sistem manajemen kepegawaian. ASN sudah tidak lagi sepenuhnya menjadi tanggung jawab pemerintah, sebab sekarang sudah ada Komisi Aparatur Sipil Negara (KASN). Dan juga dengan adanya aturan ini, menempatkan ASN sebagai sebuah profesi yang bebas dari intervensi politik dan juga menerapkan sistem karier terbuka yang mengutamkan prinsip profesionalisme, yang memiliki kompetensi, kinerja, objektivitas, dan mengedepankan sistem merit. Jadi bicara soal isu SARA, memang sudah tidak terlihat begitupun tentang kesetaraan gender, fokusnya pada proses rekrutmen lebih melihat pada kompetensi seorang ASN itu sendiri".

Berdasarkan hasil observasi dapat dilihat bahwa proses perekrutan sudah berjalan 
dengan lancar walaupun masih ada kendala terkait tidak adanya perwakilan perempuan di Jabatan Struktural, faktor utama yang menjadi penyebabya adalah kurangnnya minat perempuan itu sendiri dan juga ada banyak faktor lain seperti minimnya Sumber Daya Manusia, kurangnya kepercayaan diri dari perempuan itu sendiri. Kesetaraan gender memang diperhitungkan tetapi ini bukan menjadi poin utama, poin utama tetap pada 4 hal di atas, sebagaimana yang diungkapkan oleh Bapak Drs. Yusuf Kuahati, SU ( selaku panitia seleksi): "Dalam perekrutan ASN untuk menempati jabatan struktural kualitas tetap menjadi nomor satu tetapi tidak menutup kemungkinan bahwa soal kesetaraan juga pasti dipertimbangkan namun itu bukan menjadi hal utama. Ada pertimbangan khusus untuk perempuan tetapi yang menjadi persoalan ialah, misalkan banyak membuka lelang jabatan dimana-mana tetapi sedikit sekali perempuan yang mendaftar, sehingga dari itu kita sudah bisa mengukur bahwa minat dan motivasi dari perempuan itu sendiri masih kurang".

Jumlah ASN perempuan maupun laki-laki di lingkungan Pemda Provinsi NTT sebagai berikut Tahun 2011 : 6716 orang ASN; Tahun 2012 : 6455 orang ASN ; Tahun 2013 : 6460 orang ASN; Tahun 2014 : 6447 orang ASN ;Tahun 2015 : 6820 orang ASN. Perkembangan representasi perempuan dan laki-laki yang terjadi dari tahun ke tahun dipengaruhi oleh pola dan jumlah rekrutmen Aparatur Sipil Negara, dengan adanya perpindahan jabatan pegawai dalam bentuk promosi dan mutasi jabatan Aparatur Sipil Negara di lingkungan Pemerintah Daerah Provinsi NTT, yang kemudian juga mempengaruhi jumlah reprsentasi gender Aparatur Sipil Negara dalam menduduki jabatan struktural pada pemda provinsi NTT. Ditemukan juga bahwa dalam penempatan jumlah Aparatur Sipil Negara selama lima tahun (20011-2015) di Pemda Provinsi Nusa Tenggara Timur tidak seimbang antara perempuan dan laki-laki, kenapa saya katakan demikian karena terlihat jelas bahwa selama lima tahun itu yang menjadi Aparatur Sipil Negara banyak didominasi oleh laki-laki. Kemudian menjadi pertanyaan besar apakah proses perekrutan Aparatur Sipil Negara berjalan sesuai dengan aturan yang berlaku atau tidak. Hal ini berdampak pada kesetaraan gender dalam menempati jabatan struktural sesuai sistem rekrutmen Aparatur
Sipil Negara. Aparatur Sipil Negara laki-laki maupun perempuan sama-sama melewati tahapan dan persyaratan yang sama. Adapun jumlah Aparatur Sipil Negara yang menduduki jabatan struktural di Pemda Provinsi NTT. ASN yang memiliki jabatan eselon I. II, III, IV Jabatan eselon I dari tahun 2011, 2012, 2014, 2015 hanya berjumlah 4 orang ASN dan semuanya berjenis kelamin laki-laki. (Sumber : BPS Propinsi NTT). Jabatan eselon II dari tahun 2011, 2012, 2013, 2014, 2015 berjumlah: 213 orang ASN, yang terdiri dari 18 orang perempuan dan 195 orang laki-laki. (Sumber: BPS Propinsi NTT). Jabatan eselon III dari dari tahun 2011, 2012, 2013, 2014, 2015 berjumlah: 1.106 orang ASN, yang terdiri dari 283 orang perempuan dan 823 orang laki-laki. (Sumber: BPS Propinsi NTT). Jabatan eselon IV dari dari tahun 2011, 2012, 2013, 2014, 2015 berjumlah: 2.987 orang ASN, yang terdiri dari 1.248 orang perempuan dan 1.739 orang laki-laki. (Sumber: BPS Provinsi NTT). Dari penjelasan diatas dapat dilihat bahwa perbandingan antara perempuan dan laki-laki dalam menempati jabatan structural berdasarkan eselon tidak seimbang dan banyak didominasi oleh laki-laki. Data di atas menunjukkan keterwakilan perempuan dalam penempatan jabatan struktural masih sangat rendah.

\section{SIMPULAN}

Dalam proses perekrutmen ASN untuk menempati jabatan struktural yang lowong pada Pemda Provinsi NTT seharusnya dilaksanakan berdasarkan pada UndangUndang Aparatur Sipil Negara No. 5 Tahun 2014 yakni menggunakan persyaratan berdasarkan pada kompetensi jabatan, prestasi kerja, jenjang pangkat yang ditetapkan untuk jabatan tersebut dan tidak membedakan SARA. Berdasarkan hasil observasi yang menempati posisi pada jabatan struktural di Pemda Provinsi NTT banyak didominasi oleh laki-laki hal ini disebabkan karena minimnya Sumber Daya Manusia yang dimiliki perempuan, kurangnya motivasi dari dalam diri perempuan sendiri serta dikatakan bahwa saat dibuka lelang jabatan untuk ASN perempuan maupun laki-laki yang banyak mendaftar hanya laki-laki dan hampir tidak ada ASN perempuan yang mendaftar. Dalam penetapan hasil akhir seleksi Gubernur mempunyai hak prerogatif untuk memilih siapa yang pantas untuk menduduki sebuah jabatan. 


\section{DAFTAR PUSTAKA}

Astuti, P. (2013). Peluang PNS Perempuan Dalam Memperoleh Jabatan Struktural: Studi Kualitas Kesetaraan Gender di Pemerintah Kota Semarang. Politika Jurnal Ilmu Politik.

Azisah, S., Mustari, A., Himayah, \& Masse, A. (2016). Konstektualisasi Gender Islam dan Budaya. Makassar.

Creswell, J. W. (2016). Research Design; Pendekatan Metode Kualitatif, Kuantitatif, dan Campuran. Yogyakarta: Pustaka Pelajar.

Fakih, M. (1999). Analisis Gender dan Transformasi Sosial. Yogyakarta: Pustaka Pelajar .

Naimena, A. Y. (2015). "Rekrutmen Politik ( Kajian Pola Rekrutmen Perempuan Menjadi Kader Partai dan Menempati Jabatan Struktural di Partai Politik- Studi Kasus di PDIP dan GOLKAR Kota Kupang Tahun 2014. 12.

Nassarudin, U. (2012). Argumen Kesetaraan Gender. Nugroho, R. (2008). Gender dan Administrasi Publik. Sahirah, Setiawati, B., \& Burhanuddin. (2015). Pengarusutamaan Gender Dalam Promosi Jabatan di BKD Pemerintah Kota Makassar. Jurnal Admonistrasi Publik.

Badan Keprgawaian Daerah Provinsi Nusa Tenggara Timur

Badan Pusat Statistik, Provinsi Nusa Tenggara Timur

Undang-Undang Nomor 5 Tahun 2014 tentang Aparatur Sipil Negara

http://www.google.com.pe/url?sa=t\&source=web \&rct=https:id.m.wikipedia.org/wiki/Undang undang_Aparatur_Sipil_Negara 